His published contributions to neurology consist of a well-known book on the "Pathology of the Nervous System" (with J. G. Greenfield) and numerous articles and lectures on clinical subjects, including the Goulstonian and Lettsomian Lectures and the Harveian Oration. These reveal him as a keen clinical observer, with a deep understanding of the psychological aspects of illness. He was, indeed, a pioneer among organic neurologists in recognizing the importance of minor psychological ailments and their relationship to the major psychoses, at a time when it was considered at Queen Square that a neurologist ought not to concern himself with the functional side of neurology. His opinion on difficult cases was much sought, for he had to a marked degree the qualities of a good consultant : he was imperturbable yet sympathetic, direct and honest with patient and medical man alike--and with himself in his own unobtrusive way; and he had a strong constitution and great physical and moral endurance.

In 1928 at the height of his fame as a London consultant, Buzzard succeeded Sir Archibald Garrod as regius professor of medicine at Oxford, a position which he held for the next fifteen years. He had expected to be able to continue some consultant work from Oxford, but soon found this impossible. $\mathrm{He}$ served on the Hebdomadal Council and on numerous University committees, and was chairman of the honorary medical staff committee and later vice. president of the Radcliffe Infirmary. In these various capacities he notably influenced University policy in general, and the development of the medical school in particular.

In administrative affairs his talents lay rather in the field of conciliation and in giving cohesion to the ideas of his colleagues than as an originator. He was the engineer of Lord Nuffield's medical benefactions, the Institute of Medical Research (1935) and the scheme for enlarging the scope of the medical school (1937). It was under his guidance that an undergraduate clinical school was opened at the outbreak of war when Oxford students had nowhere else to go for clinical instruction. He was the first chairman of the medical committee of the Nuffield Provurcial Hospitals Trust, and was largely instrumental in directing its activities into the field of social medicine. In committee he could be slow and even ponderous (a manner occasionally belied by a quick flash of wit), and his patience was inexhaustible; the only sign of anger was a slight flushing of his sturdy neck and a steely glint of his eyes. He was reserved, perhaps more taciturn than the ideal University democrat, and for all his rugged honesty he was not without his moments of artfulness (as was most evident on the tennis court); but he retained to the end of his life a great tolerance and understanding of younger men, and was generously loyal to them even when they contrived to hurt his feelings.

The University of Oxford awarded Sir Farquhar the Osler Memorial Medal, he was an honorary fellow of his old college Magdalen, and after his retirement in 1943, honorary student of Christ Church; he was Extra Physician to H.M. the King and had many honours.

His last year was characteristic of him : in his work for the Hospitals Trust, though beginning to feel his years, he travelled the country in more discomfort than most men of his age would have supported. A severe heart attack in the late summer was met with his customary stoicism, his one fear being that he might live and yet not be able to work. He died suddenly before the fear was realized. H. CaIRns.

\section{Dr. L. Cernosvitov}

Tere sudden death of Dr. Lev Cernosvitov on December 15 came as a sad shock to his friends and colleagues. He was well known as a specialist on Oligochæte worms, a group which he had made his own and on which he had produced a body of work of the highest standard.

Lev Vladimirovich Cernosvitov was born in Poltava in July 1902. A few years of his early child. hood were spent in Paris, where his father, a member of the legal profession, was in exile for revolutionary activities. The family were back in Russia, however, for his school years, which were interrupted by the revolution of 1917. In 1920, at the age of eighteen, he escaped to Constantinople; and two years later he was taken, with a number of other Russian youths, to Prague, where he received his higher education, taking his doctorate in zoology in 1927.

Cernosvitov's first paper on Oligochætes was published in 1925 in collaboration with Sergej Hrabr, and from then on a steady stream of papers on this group came from his pen. Much of the material described was collected by himself in Czechoslovakia, in the Carpathians, in the Balkans and in South America. The American collections were made during 1931-32 when Cernosvitov was engaged in work on the control of insect agricultural pests, and the three interesting papers on this material that appeared in 1936, 1937 and 1942 were to have been followed by a more comprehensive work when opportunity allowed. On his return from South America, besides having to earn his living by more utilitarian tasks (experimental transplantation of teeth of mice in a dental clinic, field-work for the biological control of the spruce saw-fly, etc.), Cernosvitov was now much in demand to report upon the Oligochæte collections of many expeditions and European museums. His connexion with England occurred in a double capacity. His work on spruce saw-flies was done for the Imperial Institute of Entomology, and, after Colonel J. Stephenson's death in 1933, we looked to him for all expert work on Oligochæta. The late Rev. Hilderic Friend sent him his collections of Enchytræidæ, upon which Cernosvitov reported in 1937. The late Charles Monro, who had charge of the annelid worms at the British Museum (Natural History), was very anxious to attach him to the Museum staff as Oligochæte specialist. In $\mathbf{1 9 4 5}$ he was elected fellow of the Linnæan Society.

When war broke out in 1939, Cernosvitov was pursuing saw-fly parasites in Finland. He hurried to London, and until July 1940 was working at the Museum. Owing to war conditions, he then had to accept a post as monitor at the B.B.C., where his linguistic attainments were of value. With great determination he kept in touch with 'his worms'. He spent one of his short holidays at Bangor, where his first contact with the teeming life of the intertidal zone gave him a thrill similar to that he experienced on first meeting the tropical fauna. In 1943 he spent a couple of weeks at the Freshwater Biological Association's station on Windermere. The collections made there were later worked out at the University of Reading in his free time from B.B.C. duties, and a paper on them appeared in the Proceedings of the Zoological Society of 1945. This work, and a revision of Friend's types published in 1942, put British Oligochrte studies on a sound basis.

In addition to his anatomical and taxonomic work, 
Cernosvitov made a detailed investigation of the resorption of spermatozoa in the Oligochæta (1930) and the Turbellaria (1931 and 1932), and in 1930 he published a critical review of the literature of this subject for the animal kingdom in general. He concluded that the phenomenon was of widespread and normal occurrence, and speculated as to its physiological role. From this he took a special interest in the little-explored field of hormones in the Invertebrata.

In Dr. Cernosvitov we lose not only an able zoologist, but also a colleague of singular personal charm. He married, in 1944, Miss Nina Gartman, who is of Russian birth but British nationality, with whom all who knew him must feel the keenest sympathy. Sympathy must be felt too for his mother and brother, now in Paris, for whom the shock of his death is added to the dreary war years of uncertainty and separation.

E. Trewaras.

\section{Dr. Thomas Barbour}

$\mathrm{Br}$ the death of Thomas Barbour on January 8 at Boston at the age of sixty-one, the result of a stroke, the United States loses one of its leading biologists and Harvard one whose name will always be associated with the great Agassiz Museum. He was a member of the U.S. National Academy of Sciences ; while bodies outside the United States which had honoured him included the Zoological Society of London, which made him a foreign member.

In early life Barbour was closely associated with the Agassiz family, but his inclinations led him mainly to the study of land animals in relation to their environments. Few knew Florida so well, for his family had lived in the Everglades in friendship with the Seminole Indians, in a quite unopened country, shell and pottery mounds, swamps, forests, islets and mangrove swamps. He knew the Miami River as an almost uninhabited area, and for all his life fought to preserve Nature in this sole tropical area of the States. He visited it yearly and helped to found its University and Marine Research Laboratory.

Barbour passed an extended honeymoon, wandering, collecting and observing from Burma and IndoChina to New Guinea. On his return he settled in Boston and commenced his long series of systematic publications incorporating his field observations, principally dealing with the reptiles. He led several fossil 'digs' and wandered over most of the West Indian islands.

During the War of 1914-18 he was sent with a commission to cement a most doubtful friendship with Cuba, its temperament so different from that of Latin-America. Physically he was a very big man, a demon for work, vivacious, with a great capacity for friendships. He commenced a life-long attachment with that remarkable naturalist Carlos de la Torre, at one time president of the Republic, and was received informally and joyously by the intelligentsia all over the island, while everywhere researching and collecting its fauna. He specialized on birds, and from his notes grew the standard work on those of Cuba. Every winter he visited the island, and his support was sought for every educational development. $\mathrm{He}$ helped in the growth of the great Soledad gardens and established its important, and muchvisited, Harvard House. Other activities in this region were at Panama and Miami ; and he visited and advised upon the Kruger National Park in the Transvaal.
A man is perhaps best seen in his miscellaneous writings: Barbour's were "The Naturalist at Large", "That Vanishing Eden", "A Naturalist in Cuba", all written in partial retirement, old-fashioned in form but entirely modern in outlook. The man was a delightful personality and he made a grand time living his life. He was a friend to all science in the States, and a host to visitors to Harvard.

\section{J. Stanley Gardiner.}

\section{Dr. E. J. H. Mackay}

The Watumull Prize for 1945 of the American Historical Association, offered for works dealing with the history of India and published during 1941-44, has been awarded to the late Dr. Ernest Mackay for his last archæological report, "Chanhu-daro Excavations, 1935-36", a fitting tribute to a long career of valuable archæological field-work. Unhappily, the award must be a posthumous one, for Dr. Mackay died on October 2, 1943, at the age of sixty-three, through the strain of four years of service as an A.R.P. warden.

Dr. Mackay began his life's work under the ægis of the late Sir W. Flinders Petrie, one of whose greatest services to archæology was the training of almost an entire generation of British excavators who have worked in Egypt and Western Asia. After nearly four years of work for Mr. Robert Mond among the Tombs of the Nobles at Luxor, Mr. Mackay served with the Egypt Expeditionary Force in Palestine and Syria, and in 1919 was British member of the International Commission appointed by Lord Allenby to survey and list the Holy Places and sites of archæological interest in those countries for their protection and preservation.

After an interval as 'custodian of antiquities' in Palestine, Dr. Mackay went to Iraq in 1922 as the first field director of the Oxford University and Field Museum, Chicago, Joint Expedition to Kish; and in March 1925 he discovered the small but important mounds of Jemdet Nasr, a key site for the early history of Sumer. A call to assist with the excavations of the Archæological Survey of India at the great Indus Valley site, Mohenjo-daro, took him to India in 1926, and when the financial crisis of the early thirties compelled the abandonment of active excavations, he compiled his "Further Excavations at Mohenjo-daro, 1927-31", two volumes, a fine sequel to the great three-volume work, "Mohenjodaro and the Indus Civilization", published in 1931, in which he collaborated with Sir John Marshall and others.

During 1935-36, under the joint auspices of the American School of Indic and Iranian Studies and the Boston Museum of Fine Arts, Dr. Mackay excavated Chanhu-daro, Sind-a site which produced evidence of two cultures subsequent to the Harappa culture (of the city of that name and Mohenjodaro), a first step towards bridging a long dark gap (c. 2500-1500 B.c.) in the history of India before the coming of the Aryans.

As the only field archæologist to have excavated in all the three great river valleys-the Nile, Euphrates and Tigris, and the Indus-chief centres of early civilization in the ancient world, Dr. Mackay's numerous volumes and articles are of especial value for their wide appreciation of the contacts between the ancient peoples, racial, of art and religion, and by trade. 